Received September 14, 2018

Revised December 4, 2018

Accepted December 10, 2018

\title{
South Korea's Developmental Epoch: A New Economic Nationalism Perspective
}

\author{
KEVIN HOCKMUTH*
}

\begin{abstract}
Over the last half-century, South Korea has experienced momentous economic, political, and social transformations tied to its rapid industrialization. This paper utilizes economic nationalism as a mechanism for exploring the interplay of continuity and change across several key periods of this developmental epoch. It identifies the specific ways nationalism was incorporated into the developmental politics of the Park Chung Hee era (1961-1979) and in turn how these ideological legacies weighed upon Kim Young Sam's globalization (segyehwa) agenda (1993-1997). In pursuing these aims the paper draws from a set analytical tools developed by a group of scholars seeking to reestablish the connection between economic nationalism and the mass politics roots of nationalism itself. It finds that tracing the specific ways in which nationalism was employed in the service of economic ends during the Park era sheds light on the contentious politics of segyehwa and the particular strategies the Kim administration embraced in promoting its policies. Additionally, given the increasing prominence of nationalist politics around the globe, the paper potentially speaks to a much wider set of cases through its theoretical and empirical insights into the intersection of technical and ideological issues entwined with economic liberalization.
\end{abstract}

Keywords: South Korea, political economy, economic nationalism, development, developmental state, economic liberalization, nationalism, globalization, legitimization

* Assistant Professor, Akita International University, Japan;

E-mail: hockmuth@aiu.ac.jp

DOI: 10.16934/isr.19.2.201812.33 
South Korea as we know it today took shape in the harsh season of Park Chung Hee's authoritarian rule.

-Youngju Ryu, Writers of the Winter Republic

In many ways, the contemporary South Korean (Korea hereafter) political economy bears little resemblance to the authoritarian developmental system overseen by Park Chung Hee during his nearly two-decade reign (1961-1979). Gone are the days when the state-run financial system funneled firms into industrial pursuits that matched preordained development objectives. No longer is the citizenry subject to the severe abasement of their basic rights to speak out and organize, nor under the oversight of a pervasive system of domestic surveillance. Beginning with the restoration of direct presidential elections in 1987, Korean citizens have worked assiduously to erect a robust and wide-ranging civil society (see Shin and Chang 2011) whose power to mobilize was evinced in the recent campaign to remove Park Geun Hye from the presidency. Similarly, the last several decades have brought about a pronounced reconfiguration of the state's relation with the economy and industry as well as the underlying nature of Korea's international economic orientation. Nevertheless, amid these varied and marked qualitative shifts in the Korean political economy's structure and functions lurk the tendrils of a seemingly bygone era which underscore the weight Korea's developmental history brings to bear on contemporary society.

Efforts to grapple with the precise nature and meaning of this very interplay of continuity and change in the Korean political economy have spawned a wide ranging and often fruitful engagement. To a large extent, this exchange grows out of the foundational Korean developmental state (KDS) literature (e.g. Amsden 1989; Haggard 1990; Woo 1991; Evans 1995) and centers on assessments of the state's economic role in the wake of democratization and liberalization. The crux of the engagement revolves around whether such transformations ultimately yielded a wholly reconstituted system of political-economic organization (Pang 2000; Pirie 2006; 2008; Jayasuriya 2005) or if they merely reflect the espousal of new means for meeting abiding ends (Amsden and Euh 1993; Weiss 2003; Thurbon and Weiss 2006; Thurbon 2016). This paper contributes to this debate by moving the intersection of nationalism and political economy to the analytical fore. In doing it charts an alternative angle of approach to the aforementioned 'developmental continuity' vs. 'neoliberal consolidation' framing and thus fashions a novel means to apprehend the interplay of change and continuity in Korea's developmental epoch. In pursuit of these objectives the forthcoming analysis draws upon the conceptual tools and insights of a group of scholars endeavoring to significantly reorient an often overly staid rendering of economic nationalism (e.g. Trentmann 1998; Crane 1998; Shulman 2000; Abdelal 2001; Nakano 2004; Helleiner and Pickel 2005). 
At the most fundamental level, new economic nationalism (NEN) objects to the concept's commonplace conflation with neomercantilism, or the tenets of realist IPE theory. Rather, scholars working from an NEN perspective envisage economic nationalism as arising from the "the politics of nationalism within a society" (Abdelal 2001, 33, emphasis added). Herein lies a critical point of analytical distinction that underpins the explanatory value of the NEN framework in refining our understanding of state-society interaction over an extended period of time. Such an approach calls attention to the importance of clarifying the nature and location of the phenomena under scrutiny when employing economic nationalism as an analytical variable. Whereas in most standard uses the focus is on the utilization of a particular set of policies centered on cross border economic flows, NEN emphasizes the (often highly charged) politics entwined with infusing economic initiatives with a nationalist ethos. Though these domains of activity can and frequently do interact, they nonetheless constitute wholly different foundations which will in turn spark distinct avenues of enquiry. The contention here is that exploring the pathways etched out by the NEN framework pays significant dividends in terms of refining and extending our understanding of developmental politics in Korea during the Park era and the ways they were transmuted into the contentious politics of liberalization in the post-democratization era.

Chief among these is the opportunity to explore the centrality of nationalism in soliciting popular participation in a manner that places society at the fulcrum of Park Chung Hee's developmental authoritarian regime. To this end, the analysis profits greatly from an array of existing scholarship that, in the words of Clark and Chan (1994, 333), 'brings society back in' to the study of the KDS (e.g. Koo 1999; 2001; Moon 2005; Kim 2006, Ryu 2016; Hughes 2012). One of the key contributions of this paper is the employment of NEN as a means for infusing such insights into an analytical context more explicitly couched in the study of political economy. Furthermore, doing so yields an opportunity to examine the process of economic liberalization as more than a set of technocratic adjustments centered on macroeconomic policies and institutional recalibrations -including policies associated with mercantilist conceptions of economic nationalism. Rather, the insights garnered from exploring the specific mechanisms the Park regime used to mobilize the public's embrace of the state's economic objectives bestow an excellent set of guideposts for apprehending the significant ideological dimensions of liberalization in Korea. As such, the paper harnesses the NEN framework to draw direct points of contact between the politics of mobilization and legitimization in Park's developmental regime and Kim Young Sam's segyehwa (globalization) initiative, as well as the nature of the opposition to both. 
This said, it is important to note that though the analysis offered here is largely trained on the intersection nationalism and political economy within the Korean context, such a focus is not intended to discount, nor minimize, the host of highly impactful external influences that color the period understudy. To be sure, Korea's persistent security concerns emanating from the DPRK and its concomitant enmeshment in the U.S. Cold War alliance system served as an essential set of empirical conditions for the Park regime's nationalist-imbued ideological messaging to coalesce around (see Woo-Cumings 2005). Similarly, the evolution of the international economic order in the wake of the Cold War's expiration formed a key underlying rationale for Kim Young Sam's segyehwa initiative. Certainly, this wider context forms an essential feature of the political-economic milieu constituting Korea's developmental epoch. However, it is through applying an NEN-inspired analysis to the Korean case that this paper provides valuable insights into the manner these potent forces emanating from the external environment were refracted in ways commensurate with the Korean context and reflective of the distinct choices made regarding appropriate means. More generally, the international environment undoubtedly presents a set of ever-oscillating potentialities and opportunity costs to all national economies. However, a central premise undergirding the analysis herein is that the process of translating these possibilities in nationalist frames significantly impacts the nature of their valuation, propagation, and contestation within a society.

Finally, the above discussion points to this paper's relevance for wider concerns in the study of political economy and globalization beyond the Korean case. It stands to reason that given the current global political climate discussions of nationalism will invariably summon thoughts of Donald Trump's rhetoric and policies, the UK's looming departure from the EU, or the advance of far-right parties across the globe. Though these occurrences spring from disparate sources and bely simple categorization, what they all do indicate is that the distinct axes anchoring nationalist politics remain encoded with the prospect of significantly altering the form and content of a society's political-economic disposition. Put differently, the view of economic nationalism espoused in this account of Korea's developmental epoch envisages nationalism in any society as a receptacle in that though possessing some rigidity in its basic contours, retains the potential to be filled with a host of admixtures in the form of political- economic tracts ranging from free-market liberalism to unseemly exclusionary politics which can foment discrimination and violence (see Helleiner 2002; Pickel 2005; Hall 2005).

This study provides a detailed account of these very processes within one of the world's leading economies, long-heralded as a striking developmental success. In doing so, it demonstrates that nationalist politics and economic policy are nearly always inexorably interlinked. As such, framing the matter in this way points to a reassessment such that nationalism is not reemerging per se, but rather 
that vastly different interpretations of nationalism and the presumed attendant economic imperatives attached to them are increasingly gaining a foothold. The theoretical terrain explored in the ensuing section and its subsequent application to the Korean case present a fruitful mode of analysis for exploring the contexts contemporary nationalist movements emerge from and specifying the political and economic legacies which they draw upon as sources of inspiration or targets of repudiation.

\section{NATIONALISM AND POLITICAL ECONOMY}

This section provides an overview of a collection of scholarship that while multifaceted in its emphasis and objectives nonetheless shares a set of theoretical and methodological commitments that warrants its aggregation under a shared rubric, denoted here as NEN. Perhaps most fundamental among these shared precepts is that conflating economic nationalism with neomercantilism or statist realism hoists a one-dimensional conceptualization upon an agile domain rife with potentialities. From the NEN vantage point economic nationalism is suffused with an amalgam of social, historical, ideological, political, and indeed economic elements that are too often neglected due to the concept's winnowing to a rather narrow set of policies and actors (see Crane 1998, 55). With this key point of departure in mind, the remainder of this section builds upon this and other insights to put forward several of the NEN literature's conjectures most critical to our contemplation of the Korean case; expressly, the variability of outcomes tied to economic nationalism, its role in legitimization, and affinities with ideational approaches to political economy. In sum, the central objective is not so much to provide an exhaustive recapitulation of this wide-ranging framework but rather to tease out and explicate specific areas that most inform and advance our understanding of the KDS and its bearing on Korea's globalization initiatives that would gather steam following the end of military rule.

From the broadest level of abstraction, NEN can be seen as an outgrowth of prior enquires into the links between nationalism and the economy, particularly in conjunction with the emergence of industrial modernity. For Gellner $(2008,34)$ the very processes that interlink industrialization, the division of labor, and modern nationalism denote an "external manifestation of a deep adjustment in the relationship between polity and culture." From this perspective, nationalism takes on a fluid nature in the sense that it retains a malleability that enables its adhesion to an array of ideologies and political tracts rather than existing as a singular ideology that competes against other challengers such as liberalism or conservatism (Haas 1986, 712). Thus even market capitalism, with its ostensible ancillary commitment to commercial cosmopolitanism, can be reconceived as possessing an underlying nationalist ethic from its earliest days (Greenfeld 2001). By extension, in approaching 
issues closer to the heart of contemporary political economy and global capitalism it is notable that economic accomplishments serve not only to enhance the material well-being of a given society but also to nourish a sense of pride and stature through comparisons with other national communities (Shulman 2000, 373). Most important to the arguments advanced herein is that these observations help to elucidate the pliability that accompanies a more textured conceptualization of nationalism, particularly in exploring its intersection with economic matters.

Of course, invariably looming over such analysis is the state and its centralizing capacity in the realm of political economy. Indeed, as discussed above, it is the very appending of economic nationalism to the state, or statism, that NEN scholars find most problematic and, in a sense, the original sin which sets researchers upon a course of desiccating the concept (Crane 1998; Helleiner 2002; Nakano 2004). This critique warrants serious consideration given Anthony Smith's $(2010,12)$ conclusion that, on the whole, though a standardized definition of the nation has eluded experts in this field, one point of consonance has been that "a nation is not a state." As such, merely supplanting economic statism and its attendant policies such as tariffs, NTBs, capital controls, or subsidies for economic nationalism potentially runs afoul of the one few things scholars of nations and nationalism have been able to agree upon. Accordingly, if a nation is not a state, then the purview of economic nationalism must too extend beyond the confines of the state. Put differently, the divergent lineages of nationalism and mercantilism should caution against the notion that they can be easily merged (Shulman 2000, 366). Certainly, this does not preclude recognizing the importance of the state and state actors at the intersection of political economy and nationalism. Rather, as Crane (1998, 55, emphasis added) aptly surmises, "[s]tate and nation may overlap in various ways but national identity is not simply an expression of state interest."

At this juncture, we can turn to several of the propositions and analytical potentialities emerging from this NEN framework that hold particular value for the study of the Korean political economy. First among these is the notion that a wide range of policy postures and outcomes are compatible with economic nationalism. This observation emerges as a logical corollary to the conceptual amplification at the core of the NEN framework and invites a critical reassessment of the commonplace (neo)liberals vs. nationalists framing of investigations into the political economy of globalization. Rather than representing an outmoded or even unsophisticated attempt to stand pat in the face of new incentive structures born out of accelerating commercial mobility, this alternative view contends that the social and political choices entwined with globalization may, in fact, serve to reinforce rather than diminish the import of nationalism in the policy process (Pickel 2005).

To be sure, such an approach adds layers of complexity to economic 
nationalism absent in its more standard usage. Nevertheless, in recompense for muddying the analytical waters we are afforded the opportunity to clarify and edify a term which Derek Hall $(2005,124)$ finds too often functioning as a repository for "policies of which liberal economists disapprove." At the same time, Hall (119-124) recognizes that an overly broad conceptualization of economic nationalism carries the risk of being rendered non-operational if construed as omnipresent. As such, he suggests that it is incumbent upon the researcher to demonstrate the specific ways in which nationalism animates and informs the political-economic discourse. This paper endeavors to heed this advice in its exploration of the Korean case.

These insights direct attention to the nature of the processes through which a given set of outcomes emerge and importantly the "webs of cultural meanings and practices" that inform them (Trentmann 1998, 219). This observation is tied to another critical domain of NEN which significantly augments the analytical instruments at our disposal, namely legitimization. It is in the exploration of this crucial-if fraught-concept that the essential role of nationalism and national identity come to the fore as they embody well-worn channels for articulating values to buttress specific policies or a broader set of economic commitments. This remains an enduring feature of political economy to the extent that nationalism often serves as the central axis upon which economic policies (and outcomes) are legitimated (Levi-Faur 1997; Pickel 2005). Taking the level of abstraction one step further, nationalism can be conceived as an elemental component of the very substance that demarcates the parameters of a legitimate political order (Calhoun 1993, 235; Breuilly 1994, 25). Furthermore, focusing on the intersection of nationalism, economy, and legitimacy moves the analysis beyond questions of efficacy and aggregate welfare and towards considerations of the terrain upon which policies are promoted and contested within the wider social environment. The contention here is that the parlance of such initiatives is commonly some dialect of nationalism and moreover that it is precisely the seemingly endless malleability of nationalism that makes it simultaneously vexing to scholars and alluring to political actors of all stripes.

This discussion provides an opening to questions of how state actors set about engaging the public and engendering their support, or acceptance, for a given political economic framework. Specifically, it highlights considerations of the extent to which positive economic performance and improving material conditions bestow legitimacy by the very nature of their realization. Certainly, the notion that greater prosperity can (and does) serve as a major engine of legitimization is a rather uncontroversial proposition. However, investigations into the correlation between individuals' location in a socio-economic order and the ways they construct their own beliefs about the relative efficacy of competing economic policies (e.g. trade) caution against the impulse to impute a one-to-one 
relationship (see Vogel 1999; Mansfield and Mutz 2009). Moreover, nationalism may serve as a means to manage or temper the citizenry's economic expectations by way of extending time horizons (Levi-Faur 1997, 170). Often this is accomplished via exhortations linking "the past to the future with arguments about historical destiny" (Abdelal 2001, 25). Notably, Abdelal (28) further adds that such invocations must demonstrate a degree of congruence "with the prevailing construction of historical memory." Though this avenue of analysis is certainly far from exhausted, at a minimum, it calls attention to the potential limitations of ascribing valuations of legitimacy based upon measures of economic performance alone. The NEN framework opens lines of inquiry that allow for situating these undoubtedly important tangible outcomes within a broader backdrop of the social, historical, and ideological context they operate in.

Furthermore, casting an analytic hue of this sort presages a consideration of the role ideas in political economy and their crucial function in a process closely interlaced with legitimacy which Gourevitch $(1989,87)$ dubs the mobilization of consent. Bringing ideas to the foreground helps to take the preceding discussion one step further by precipitating a reevaluation of the very demarcation that tends to quarantine ideational factors from material or 'interest' centered ones. Such a frame of reference can be viewed as drawing upon the insights of Polanyi who considered the idea/material bifurcation a source of misapprehension in the identification and representation of interest (Block and Somers 2014, 58). Similarly, Blyth $(2002,17)$ finds that proceeding from these dualistic assumptions leads to a faulty disambiguation of ideas from interests. ${ }^{l}$ Dispensing with this distinction opens the possibility to invert the interest $\rightarrow$ outcome causal sequence and entertain the "possibility of human dispositions being the dependent variable" (Gellner 1968, 260). The import of this perspective for NEN analysis is clear to the extent that nationalism in general, and within the context of legitimizing political economic orders more specifically, is always wed to a succession of imagining, forgetting, and reinventing (Crane 1998, 55); or, as Benedict Anderson $(2016,12)$ eloquently formulates, an alchemy that transforms "chance into destiny."

\section{NATIONALISM AND DEVELOPMENT IN THE PARK CHUNG HEE ERA}

This interplay of chance and destiny serves as an apt heuristic for considering the Park Chung Hee era in the broadest sense. Certainly, chance played a manifest role in creating the conditions that allowed Park and his associates to seize power in a nearly frictionless coup in May 1961. And though it is difficult to imagine that even Park himself could have anticipated the magnitude of the chain of events to be unleashed forthwith, he nonetheless set 
about with great zeal in morphing such serendipity into a historic singularity. Thus, in his 1962 treatise, Our Nation's Path, Park (1970a, 119) shows no compunction in broaching the grandiose, postulating that "[i]n the past [Koreans] did not have the eyes to observe our history $\cdots[$ it] was a record of people constantly groping in the dark. Now is time for us to take a new view of Korean history." In this formulation, he is no less than marking out his regime as a beacon restoring vision and clarity of purpose to a nation that he argued had hitherto been bereft of both. The sheer scale of the social, political, and economic transformations that inhabited nearly every corner of the Korean body politic by the time of his assassination in 1979 lends retrospective credence to the view that Park's rule functioned as a historical watershed. Whether a sight was indeed restored or if the historical landscape was left all the more blotted and opaque is a question that lurks beneath the surface of Korean politics up to the present day (Moon 2009).

\section{Korea as a Case of Successful Development}

As this work is primarily concerned with matters of Korean political economy, it is perhaps best to turn first to the aspects of Park's reign that distinguish him from the host of authoritarian rulers that populated the Cold War landscape, namely Korea's nearly unparalleled rapid industrialization. The KDS literature occupies a central location within scholarly exploration of the causes behind Korea's exceptional developmental experience. To be sure, outside of its general East Asian bent research categorized under the 'developmental state' rubric encompasses a diversity that tends to hinder a precise characterization. This said, accounts centered state autonomy and technocratic competency which emphasize a "cohesive set of institutions with a relatively autonomous capacity to implement a planned strategy for capitalist economic growth" tend to form a baseline for KDS studies in political economy research (Stubbs 2009, 5).

However, given this paper's focus, it is perhaps most important to highlight existing KDS scholarship that accentuates the nationalist characteristics of Park's developmental regime. Several important contributions provide thoughtful explorations of the ways in which Park's own nationalism provides a window into the underlying motivations driving his decision-making (e.g. Kim 2011; Moon and Jun 2011; Thurbon 2016). Similarly, Woo-Cumings (2005) underlines Korea's tense security environment as a source for ideological content aimed at hastening the pace of industrialization and reducing (or eliminating) social friction. Furthermore, Thurbon (2003) makes a convincing case that understanding the ideational underpinnings of the KDS is essential for grasping not only the sources of rapid industrialization but also the interplay of continuity and change which lies at the center of this study. 
The analysis presented in this paper builds upon these works by further refining our understanding of the specific means thorough which developmental politics persistently traversed the state-society frontier during the Park era and their impacts both contemporaneously and moving into to future periods. Further, rather than directly contesting the more standard institutionalist account the KDS political economy, the contention here is that exploring the modalities of social activation-and resistance to them-elucidates the clear nexus between the emotive politics of nationalism and the more technocratic functions of the developmental state. Mapping an NEN approach onto the KDS reveals important points symbiosis between technical economic governance and ideological mobilization. In this way, we are able to grasp the significant ways in which the KDS during the Park era profoundly shaped society and its perspective on the economy.

\section{Development, Nationalism, and the KDS}

Thus, the central goal is to consider the political economy of the Park Chung Hee era from the vantage point of how elites interacted with society in their efforts to 'mobilize consent' for the state's developmental objectives. As such, the analysis homes in on the pronounced and impactful ways that the state sought to subsume and (re)orient the content of social discourse and (re)construct it in ways that cohered with its aspirations. Through such an accounting, NEN's emphasis on bringing the 'nationalism' back into economic nationalism pays significant dividends in the sense of returning to its origins as a phenomenon inherently associated with mass politics and modernization. ${ }^{2}$ Dong-No Kim (2013, 145, emphasis added) concisely captures this egalitarian ethos at the heart of nationalism in modern societies in that it is, "above all, an ideological force that enables the horizontal integration of individuals."

In this way, whereas more standard KDS models tends to envisage a 'weak society' to be kept at bay and sequestered from the policy process, this approach emphasizes the processes and ideas through which the Korean public was activated and ushered into the developmental fold. By extension, this framework of analysis also draws attention to the counter-ideological narratives and practices that arose in opposition to Park's developmental enterprise and its pillars of legitimization. This investigative vantagepoint extends our understanding of the developmental politics under Park as well as key contextual elements of the Korean political economy in the post-Park era.

Thus, focusing on the intersection of nationalism with legitimization and public mobilization points to its centrality in the state's developmental initiatives during Park's reign. Importantly, it builds upon a perspective that economics comprised only one facet of what Park envisioned as a far more encompassing 
drive towards modernization (Shin 1998, 153). Through its vigorous and unyielding messaging to the public the state endeavored to cultivate what Shin $(2006,14)$ labels a 'developmental ethic.' This ethic was heavily, if not entirely, rooted in a highly emotive, viscid nationalism which "came to encompass the entire content of modernization" with the formation of a robust industrial economy serving as the ultimate signifier of its realization (Kim and Park 2003, 41). More specifically, it provided an effective means for meeting several interlocking core objectives simultaneously such as fortifying the regime, advancing developmental causes, and marshaling the public towards the support of these objectives (Moon and Jun 2011, 123). In sum, developmentalism in the Park era is rendered nearly indecipherable absent a clear apprehension of "how the state utilized cultural and historical legacies to achieve its objectives" (Kim 2006, 5).

\section{History, Security, and Labor in the National Imagination}

Undoubtedly, the state's employment of a distinctly stylized historicism stood at the forefront of its messaging to the public. Further, exploring the regime's efforts to construct a vision of the imperatives born of Korea's historical location highlights the centrality of the international context in fashioning such messaging. Chief among these were direct references to the Joseon Dynasty's (1392-1910) incompetence resulting in failures to progressively adapt to the rapidly changing international environment. From this perspective, the foreboding international climate and precarious domestic political conditions confronting Korea were interpreted as necessitating a clean break with the past, especially in terms of the public's attitude and mindset. Thus, in Park's (1970a, 118) stark assessment modern Korean history evinced "a record of failures, national ruination and confusion." To this effect, he wove an account that both affirmed Korea's failed or unrealized historical mission and-perhaps rather unsurprisingly - cast his revolution as the harbinger of a coming redemption by dint of transcending the errors that plagued these misbegotten centuries. In this sense, such an interpretation was intimating an ancient undertaking to conjure a sense of awakening among the public and galvanize "a health always latent but never achieved in Korean history" (Hughes 2012, 136).

In further pursuit of engendering this historical narrative within the body politic, the state etched out a position as the ultimate authority on what exactly constituted 'national culture' and by extension stifled discourse that could be associated with alternative avenues of national deliberation (Wells 1995, 16-24). Such insights into this period speak directly to the theme of legitimization explored in this paper. Moreover, considering the role of historical framing and imagining details how the citizenry was entreated to locate their active participation in the regime - via work or other state-sanctioned activities ${ }^{-}$within 
the state-ordained mission to surmount centuries of crisis, calamity, and tragedy. Such a perspective broaches a fundamental point advanced herein by identifying the specific historical framing that represents the agency and intentionality of the KDS in translating its international position into ideological material for bolstering legitimacy and active participation.

However, if such a historical rendering crafted a contextual milieu that defined the broader contours of the ideational environment, the atmosphere of threat and persistent siege tied to the DPRK, communism, and the wider Cold War supplied a far more immediate basis for ideological mobilization. Here too, it is important to note that while such a context is certainly influential in shaping the parameters of available options it is by no means expressly determinative of a specific course of action. As such, in the context of the KDS under Park messaging derived from Korea's security environment were interlaced with the aforementioned dour historical diagnoses. In this manner, existing threats to Korea precipitated an imperative to jettison what Park concluded was the overly effete culture that permeated Joseon society and mint a new marshal ethos (Jager 2003, 95-6). ${ }^{3}$ However, it as at the intersection of nationalist messaging, developmentalism, and the lived experience of the public where we are able to glean how the regime instituted an ideological basis for the regimented society it aspired towards. Conscription and industrialization were intimately linked to the extent that at times recruits found themselves deployed to factories (Moon 2005). This represented a rather literal manifestation of the regime's moniker, 'industrial warrior' as well as similar terminology such as "constructing while fighting," "export war," and the "occupation of ten-billion dollar export hill" (Bae 1989, $362)$. Hagen Koo $(2001,12)$ characterizes such language as indicative of efforts to engender laborers' identification "as soldiers involved in an economic war against foreign competitors, willing to sacrifice themselves for the glory of the nation."

This integration of military affairs, Cold War politics, industrial policy, and ideology reached an apogee in the regime's agreement to deploy its soldiers to Vietnam. In addition to sending over 300,000 soldiers to the war, Korea's participation catalyzed Park's drive for a militarized industrialization by way of the significant economic benefits accrued through contracts with the U.S. military (H. Kim 2004, 206; Kimiya 2011, 75). The revenues derived from Vietnam War-related business would provide the core financing for several of the industrial conglomerates (chaebol) that would come to dominate the economic landscape in ensuing decades (J. Lee 2010, 41). However, just as Park's vision tended to couch such marshal and industrial pursuits in a broader web of modernization, Korea's participation in Vietnam was also quarried for ideological content that celebrated its auspicious indications of a nation on the rise. To this effect, public messaging extolled the valor of the Korean soldiers as the first sent 
abroad to fight (42). The public was entreated to directly participate in the adulation via rallies to welcome the returning soldiers under the slogan 'They've Returned Victorious' (43). Thus, reflecting on the multidimensional nature of Korea's involvement in the Vietnam War crystallizes the near inseparability of militarism, industrialism, nationalism, and legitimization in the developmental program overseen by Park. This apprehension, in turn, highlights the ways the KDS embedded itself within in society in terms of both its messaging to the citizenry and their direct experiences of 'development.'

Of course, for a great many Koreans such experiences involved grappling with a host of social controls including dire labor conditions. It is difficult to overstate the centrality of labor in Korea's industrialization and export-driven growth model. Eckert $(1993,113)$ identifies the abundance of low-cost, relatively high-skilled labor as Korea's sole enduring basis of comparative advantage which explains why both political and economic elites "used every means at their disposal, including the use of police and hired thugs to ensure that labor costs $\cdots$ remained as low as possible." Similarly, workers in Korea were subjected to strikingly high incidences of industrial accidents and other hazards in the name of accelerating the pace of industrialization and growth (M. Kang 2011, 172). Nevertheless, despite such harsh treatment workers were continuously assured that this state of affairs was only 'temporary' and that their acquiescence would reduce the timeframe that poor work conditions were 'required' (Bae 1989, 362). As such, the populace was encouraged to ponder this "imagined future" to extend their time horizon when assessing the regime's legitimacy (Nelson 2000, 21). For his part, Park (1970b, 141, emphasis added) crafted his appeal for accepting the state's "firm hand" in the form of an agricultural allegory asserting that,

Often it is inevitable to use strong force other than law. The people must understand this and bear it with a cooperating heart. A revolution is like the farming of a year. How the farmer toils for his harvest in the autumn! Present sufferings must be born for the fruits of tomorrow. Without this sacrifice, without this payment, the harvest of autumn will not be.

Thus, the state's heavy-handedness was simultaneously acknowledged and marked out as an essential component for attaining national aspirations. Taken as a whole, these dedicated efforts to reorient the public's thinking towards matters of politics, economics, nation, and their intricate interrelation with one another constituted an "extreme form of social control and national mobilization" (Pak 1998, 56). Mass media and the education system operated as key hubs of disseminating the state's position to the public (S. Moon 2005, 45; Pai 2000, 3; Ryu 2016, 11-17). The intensification of these efforts in the 1970s elevated the role of the regime's rhetoric in day-to-day life to a degree whereby it "permeated 
citizens' identities" (J. W. Kang 2012, 694). Ryu (2016, 20) emphasizes the role of microscopic surveilling at the neighborhood level in facilitating the subsumption of more localized identities under state auspices. In this manner, thoughts and actions at the individual level often demonstrated a high degree of congruence with the regime's ideology which at its core sought to spawn an "organic integration between nation and individual subjects" (J. W. Kang 2012, 695). Thus, beyond merely developing a set of interlocking claims that bound together history, militarism, and development the Park regime exhibited a keen ability to translate such macro-ideological propositions into meaningful results at the local and individual level. Calhoun $(1993,232)$ stresses the import of the very immediacy of nationalist entreaties in that they are able to foster a willingness to sacrifice through linking the "biographies of individual persons and of the nation as a whole."

Indeed, these efforts resonated with a sizable portion of the populace, undoubtedly due in no small part to the ability of the regime to make good on its promises of rapid economic expansion, the alleviation of poverty, and opportunities for social mobility. At the same time, the above analysis makes clear that the activation of the populace through emotive nationalist framing was central to the state's developmental program in terms of fomenting participation and enhancing legitimization. Furthermore, even from a strictly economistic frame of reference, the zealousness with which the Park regime pursued the cultivation and dissemination of its ideological messaging is indicative of an apprehension that growth in and of itself would not be sufficient to legitimate the harsh conditions the citizenry was compelled to bear. And for a vocal opposition that - as with the economy - would grow and gather pace as Park's time in power progressed, neither rapid industrialization nor the state's dedicated efforts to cloak its activities under the banner of national revitalization would prove sufficient in legitimating the regime.

Importantly, nationalism and oppositional nationalist framing would form the core of these resistance efforts that would employ an alternative set symbols and historical rememberings in carving out a civil space beyond the state's sweeping purview (Koo 1999, 55-6). A significant point of punctuation in opposition politics during the Park era emerged from the widespread and raucous street politics protesting negotiations with Japan that would result in the 1965 normalization treaty (Park 2011, 380). Here the sharp divergence regarding what constituted 'genuine' national interests or obligations are made plain. What the Park regime viewed as an incontrovertible prerequisite to economic recovery and expansion, opponents derided as a scheme to forsake, in the name of modernization, "full decolonization and give up in perpetuity [citizens'] private claims against the former colonial ruler" (Ryu 2016, 32). ${ }^{4}$ To be sure, the goal here is not to educe a conclusive valuation of the treaty's efficacy or 
appropriateness but rather to emphasize the centrality of nationalism and nationalist politics entwined with policies geared towards advancing the cause of industrialization.

This early manifestation of dissent prefigured the emergence of a dissident politics that called into question not only the regime's historical standing but also the veracity of its claims regarding the necessity of authoritarianism, state violence, and labor repression. These instruments of control reached an apex in 1975 with the issuance of Emergency Decree \#9 that essentially made all political activity illegal. This hermetic sealing of civil society brought about "a keen sense of deprivation and alienation from the sociopolitical system" that rising income alone proved incapable of alleviating (Choi 1993, 29). In sum, just as the Park regime made significant efforts to meld a redemptive nationalism with its economic initiatives, so to would those standing in opposition graft their struggle for political and economic rights on to a sweeping nationalist tableau that offered a wholly distinct historical accounting of Korea's location at that moment in time.

\section{NEN and the Park Chung Hee era}

The preceding analysis demonstrates how nationalism and the economy interacted and became inexorably interlinked over the course of Park Chung Hee's rule in Korea. Most importantly, it highlights the specific means employed and how those choices forged a set of ideological legacies in tandem with the institutional patterns that arose during this time. In doing so, this section exhibits NEN's conceptual innovations through their capacity to augment and advance our understanding of this pivotal phase in the Korean political economy. More specifically, NEN's focus on the constitutive role of nationalism homes in on the contextual parameters informing the regime's messaging and its subsequent permeation of popular discourse. Exploring such matters emphasizes the manner in which historical framing, militarization, and the extension of time horizons all played a significant role in shaping the nature of public attitudes and conceptions of interest within the context of the state's objectives.

To this end, resituating our conceptualization of economic nationalism in a way that reconnects it to the mass politics origin of nationalism itself enables a consideration of both the state's prerogatives in fashioning a dominant ideology and the manner in which these ideas are digested, altered, and potentially reconstituted once in the hands of the citizenry. Above all, a clear outcome emanating from this period is nationalism's emergence as the central axis of contestation in Korea's political economy. Further, it would continue to shaped the terms of engagement animating political discourse and economic policymaking long after Park's assassination. It is in this regard that NEN analysis produces meaningful guideposts for identifying the underlying forces of change and continuity 
in Korea's developmental politics that arise in the wake of democratization and amid efforts by political elites to promote a new economic outlook.

\section{SEGYEHWA: A NEW TERRAIN FOR (NEW) ECONOMIC NATIONALISM}

In February 1993, Kim Young Sam was sworn in as the first wholly civilian president in over three decades. The just over thirteen years that elapsed between Park's death in late 1979 and his assumption of office were shaped by the continuation of authoritarian rule under Chun Doo Hwan which was bookended by the horrific events in Gwangju in May 1980 and the resumption of direct presidential elections and political liberalization following the June 29 declaration in 1987. It is also important to note that the 1980s coincided with both slow but significant movements in the direction of economic liberalization from above and the coalescence of a nationalist-inspired democratic resistance movement known as the minjung undong from below. Given that Roh Tae Woo, a former general and close Chun associate, had prevailed in the first presidential contest following the resumption of free elections, the victory of long-time democracy advocate Kim Young Sam ushered in hopes of making a clean break with Korea's nearly ceaseless stretch of authoritarian rule since its founding in 1948. Kim had campaigned as a representative of the middle class and small businesses promising to end the state's excessive attention to big business and make the economy work for all Koreans.

To this end, his signature segyehwa (globalization) agenda was touted as a means of propelling Korea towards 'advanced nation status' by dismantling all lingering vestiges of the state-driven developmental economy (Kihl 2005; Moon 1999). The policy course enumerated by the segyehwa agenda reflected a commitment to technical adjustments broadly derived from neoliberal precepts. The underlying premises buffeting the agenda were twofold. First, the accelerating pace of economic globalization rendered Korea's state-centered developmental model unsustainable. Moreover, a conviction took hold that in the absence of reforms to counteract waning inflows of foreign investment the Korean economy risked being left behind in the race for technological advancement (Kim 1997, 5). Second, implementing the liberalization measures deemed necessary to overcome these barriers would in turn satisfy long-standing social demands for curbing the "chaebol's monopolistic and abusive business practices" (Lee 1997, 381). This coincided with dedicated state initiatives to strengthen and fortify Korea's SMEs as a means to promoting greater economic equality (Kim and Mo 1999). However, given the emphasis of this study, the matters of greatest interest are located in the nature and intensity of the resistance to the reforms and the Kim administration's efforts to quell discontent 
Despite directly linking segyehwa's liberalization agenda to the fortification of a more equitable, democratic order, Kim faced significant resistance on multiple fronts from the very outset of his term. During his first year in office, he found himself on the defensive and facing largescale street demonstrations surrounding the volatile issue of Korea's ban on rice imports which doubled for widespread discontent with the direction of the Uruguay Round negotiations and liberalization initiatives writ large. Similarly, his efforts to promote Korea's accession to the OECD as a symbol of reaching the upper echelons of global economies was met with public opposition to implementing the reforms required for membership (Saxer 2013, 185). Beyond the wellspring of societal discontent, Kim's reform efforts also ran into significant bureaucratic roadblocks, especially within the Ministry of Finance, due to a belief that the policies were overly hasty and potentially destabilizing (Thurbon 2003). Additionally, a Bishop (1997) point out that a large portion of bureaucrats at this time were predisposed by training and ideological commitments to stymie segyehwa's liberalizing impulses.

These incidences provide a brief window into the ways that the nationalist politics that underpinned economic policy during the Park era continued to operate under a different set of conditions. The important takeaway is that the politics of liberalization in Korea is commonly infused with a heightened intensity born of its being absorbed into far more emotive categories. Additionally, though they were certainly coming from different perspectives, it is noteworthy that active efforts to derail segyehwa's economic reforms bubbled up both from the public - often in the form of boisterous street politics - and within apparatuses of the state itself by way of obstinate officials within the bureaucracy. The preceding analysis makes it clear that Kim administration saw the package of liberalizing reforms as not only essential to Korea's long-term economic viability but also part and parcel to meeting long-standing social demands to check the chaebol's influence and apportion the fruits of industrialization more equitably. However, even if these assertions were indeed accurate, segyehwa's ideological attributes represent a fairly unambiguous acknowledgement by its proponents that its more technical components must be married to a program that both harnessed existing nationalist frameworks and, more boldly, revamped their very foundations.

\section{In Search of the 'Global Mind'5}

To this effect, segyehwa's messaging reflected the amalgamation of national aggrandizement and recollections of historical failings that harken back to Park Chung Hee's rhetoric. The public was encouraged to envisage Korea joining the ranks of the world's most 'advanced' nations while simultaneously bearing in mind that amid the tectonic transformations of the late nineteenth century "Korea had failed to reform and subsequently became a Japanese colony" 
(Shin 2006, 144). Thus, just as with Park's ideological messaging, Koreans were encouraged to learn from the 'lessons of history' and imagine a future where Korea would take its seat among the foremost nations in the world (Cho 2008, 86). ${ }^{6}$ However, considering that most Korean citizens would likely find such an ascent, in and of itself, generally unobjectionable, framing matters in these terms implied the acceptance of policies that may appear distasteful to the public's sensibilities. This recalls the theme of extending temporal horizons in an effort to redirect public appraisal of policies. What is particularly interesting here is that the concerns that Kim administration was seeking to assuage can be traced to the very ideological material the Park regime had engendered in the public for decades.

As a result, segyehwa included a focus on transforming the public's mindset and perceptions of national interests to facilitate "the nurturing of more open and globally oriented attitudes among the Korean people" (Cherry 2007, 43). Importantly, rather than being a mere ancillary component of economic liberalization initiatives, reorienting public attitudes were construed as central to the process. From the view of its architects and supporters, this component of segyehwa was a necessary condition for instituting a liberal economic order by propelling the abandonment of what Samuel Kim $(2000,257)$ labels the "Hermit Kingdom complex." Kim (258) goes on to recount the views of Lee Hong Koowho served as Prime Minister under Kim-that alleviating this 'complex' necessitated abandoning "rigid neo-Confucian ethical concepts, the myth of national homogeneity, limited experience with cultural diversity, fear of foreign powers, and anti-internationalization." Professor Park Young Chul of Korea University echoed these sentiments in his assertion that, for internationalization efforts such as Kim's segyehwa initiative to truly take hold, "there must be a reevaluation of the deeply-rooted exclusionist thinking in our culture" (quoted in Sohn 1993, 22, emphasis added). It should be noted here that a key contribution of this paper is closely tied to identifying important foundations of these 'deep roots' in Korea's developmental history. For his part, Economic Planning Bureau (EPB) chief, Lee Kyung-Shik, contended that such new thinking must also take hold among bureaucrats who needed to "change their mindset and stop discriminating against foreign business concerns operating here" (quoted in Sohn 1993, 22). At the level of the individual, the state initiated an ad campaign that encouraged citizen's to ponder questions such as: 'Who is your competition?' Public advertisements of this sort sought to reinforce the notion that "individual ability to compete is the most crucial human capital for national empowerment" (S. J. Park 2011, 109).

These diagnoses and prescriptions are reflective of a broader tendency among segyehwa partisans to chasten developmentalist economic ideas as outmoded and out of touch with new economic imperatives. However, the 
critiques of 'exclusionary' nationalist thought maintained a somewhat discordant coexistence with appeals to embrace segyehwa as a pathway to national greatness. In Shin's $(2006,208)$ assessment, this amounted to the appropriation "of globalization for nationalist goals." Most importantly, segyehwa's social and ideational components demonstrate that liberalization in Korea was constrained and attenuated in meaningful ways by the ideological legacies emanating from the Park Chung Hee era. It is at this nexus of economic liberalization, the campaign to foment new public thinking, and the societal resistance to such efforts that the value of NEN's attention to the contextually sensitive nature of legitimization becomes most readily apparent. The Park era had imparted a playing field whereby a highly charged variant of nationalism operated as a focal point of Korean politics regardless of one's goals or orientation.

Suffice to say, in the final analysis segyehwa received very few plaudits and many scholars place a significant degree of the blame for the outbreak of the financial crisis in 1997 on what they contend were either misguided or poorly sequenced reforms (e.g. Chang, Park, and Yoo 1998; Chang 1998; Thurbon 2003). At the same time, it bears mentioning that, in spite of the calamitous economic events of 1997-98, the two decades following democratization coincided with continued significant economic improvements. Incomes continued to rise, technological capacity rapidly accrued, and the opening of civil society fostered far greater public participation in the policy process. To be sure, there is a case to be made that when viewed in total, liberalization was an essential ingredient in ensuring Korea's continued economic expansion in the post-developmental state era (see Pirie 2008, 1-16). Furthermore, the dilemmas emerging from the ideological legacies discussed here mirror institutional incongruities that coincided with liberalization and continued to muddle state economic initiatives for decades to come (Lechevalier, Debanes, and Shin 2017). All this said, the chief point of emphasis here is that segyehwa's policies-regardless of their technical meritswere forced to grapple with the ideological legacies imparted from the Park era.

In this context, it is the particularly dour assessments of segyehwa's efforts to reshape the 'Korean mindset' which provide a further layer of insight into to the intersection of nationalism and economy. Han Sung Joo, a principal architect of the segyehwa initiative, vented his vexation with the results, labeling Korean society as ultimately "parochial" and bounded by "particularistic proclivities" (C. Lee 2000, 194). Samuel Kim $(2000,263)$ concurs that no such paradigm shift in public attitudes materialized and if anything, the younger generation "tend to be more isolationist, nationalist, and leftist than older generations." Finally, turning again to former PM Lee Hong Koo (quoted in C. Moon 1999, 11, n.3) who-in fairly revealing comments-laid bare that in the final estimation the language of segyehwa is perhaps best seen as: 
Something like a panacea. Globalization has often been used as the powerful tool for persuasion in dealing with bureaucratic or political opposition to government policies. Those who opposed globalization were branded as parochial, collective egoists. Indeed, it has served as the foundation of social consensus.

Indeed, a key insight born of the analysis herein is that filtering such assessments through the context of the highly-charged language and imagery so prominent during the Park era provides a means adding depth and nuance to commonplace assessments of Korean society as immutably nationalistic and parochial in its outlook. Put differently, the limitations of segyehwa's attempted ideational transformation are better grasped by anchoring apprehensions of these countervailing forces to explicit accounts of their ideological precursors. In this way, our understanding of segyehwa and liberalization Korea more generally is enhanced by recognition of the ways in which economic activity was elevated to a national project that encompassed far more than profit and accumulation. Interestingly, both adherents to, and opponents of Park's brand of developmentalism could identify distinct nationalist rationales for opposing Kim Young Sam's segyehwa agenda.

\section{CONCLUSION}

Reflecting upon economic reform initiatives in Korea during the 1980s Jung-en Woo $(1991,187)$ surmises that liberalization in Korea amounts to an "agenda without a noticeable domestic constituency" which may simply reflect an ethos that places greater stock "in nationalism than in individualism." This paper has demonstrated how the ideas and concepts tied to the NEN framework provide a roadmap for exploring the foundations of such inclinations. Furthermore, framing economic nationalism in Korea within a broader socio-historical context including the ideological legacies of the Park era offer important insights into the form and content of Korea's increasing engagement with the global economy. This by no means implies that such legacies are the sole determinants of how the issues emerging from economic globalization are adjudicated in Korea. Rather, the preceding analysis has demonstrated why a fuller accounting of this context is critical for understanding the terms upon which such engagements take place.

This said, considering that the segyehwa agenda came and went over two decades prior, an obvious rejoinder may query whether such a mode of analysis remains relevant into the present. I would contend that not only do the key concepts and variables at the center of this paper remain relevant in understanding more recent affairs in the Korean political economy, but that the NEN method of analysis is of clear import for the study of the contemporary global political 
economy more generally. As alluded to in the introduction, the analytical approach offered in this paper holds out great promise for improving our understanding of the recent outbreak of nationalist politics across the globe. To be sure, these phenomena are certainly tied to a host of causal factors. However, as this paper demonstrates in the Korean case, delving into the specific intersections of nationalism and economy in state's social, political, and economic history provides a fruitful path to illuminating key sources of these ongoing political permutations, be it in the U.S., Hungary, Brazil, or elsewhere. Just as Peck (2010, 16) contends that our understanding of neoliberalism must arise from "concretely grounded accounts of the process " chiseled out of the interstices of state market configurations," so too must our accounts of economic nationalism be etched out of the deep-seated mechanics underlying nationalist politics. The hope is to develop this further in future work, both in terms of the Korean case and more general theoretical research.

\section{REFERENCES}

Abdelal, Rawi. 2001. National Purpose in the World Economy: Post-Soviet States Comparative Perspective. Ithaca: Cornell University Press.

Amsden, Alice H. 1989. Asia's Next Giant: South Korea and Late Industrialization. New York: Oxford University Press.

Amsden, Alice H. and Yoon Dae Euh. 1993. "South Korea's 1980s Financial Reforms: Good-Bye Financial Repression (Maybe), Hello New Institutional Restraints." World Development 21(3): 379-390.

Anderson, Benedict. 2016. Imagined Communities: Reflections on the Origins of Nationalism. Revised ed. London: Verso.

Bae, Kyu Han. 1989. "Labor Strategy for Industrialization in South Korea." Pacific Affairs 62 (3): 353-363.

Bishop, Bernie. 1997. Foreign Direct Investment in Korea: The Role of the State. Aldershot, UK: Ashgate Publishing Ltd.

Block, Fred L. and Margaret R. Somers. 2014. The Power of Market Fundamentalism: Karl Polanyi's Critique. Cambridge: Harvard University Press.

Blyth, Mark. 2002. Great Transformations: Economic Ideas and Institutional Change in the Twentieth Century. New York: Cambridge University Press.

Breuilly, John. 1994. Nationalism and the State. 2nd ed. Chicago: University of Chicago Press.

Calhoun, Craig. 1993. "Nationalism and Ethnicity." Annual Review of Sociology 19: 211-239.

Chang, Ha Joon. 1998. "Korea: The Misunderstood Crisis." World Development 26(8): 1555-1561.

Chang, Ha Joon, Hong Jae Park, and Chul Gyue Yoo. 1998. "Interpreting the 
Korean Crisis: Financial Liberalisation, Industrial Policy and Corporate

Governance." Cambridge Journal of Economics 22 (6): 735-746.

Cherry, Judith. 2007. Foreign Direct Investment in Post-Crisis Korea: European

Investors and 'Mismatched Globalization'. London: Routledge.

Cho, Young Han. 2008. "The National Crisis and De/Reconstructing Nationalism

in South Korea during the IMF Intervention." Inter-Asia Cultural Studies 9 (1): 82-96.

Choi, Jang Jip. 1993. "Political Cleavages in South Korea." In State and Society in Contemporary Korea, edited by Hagen Koo, 13-50. Ithaca: Cornell University Press.

Clark, Cal and Steve Chan. 1994. "The Developmental Roles of the State: Moving Beyond the Developmental State in Conceptualizing Asian Political Economies." Governance 7 (4): 332-359.

Crane, George T. 1998. "Economic Nationalism: Bringing the Nation Back In." Millennium 27 (1): 55-75.

Eckert, Carter J. 2016. Park Chung Hee and Modern Korea: The Roots of Militarism 1866-1945. Cambridge, Massachusetts: The Belknap Press of Harvard University Press.

. 1993. "The South Korean Bourgeoisie: A Class in Search of Hegemony." In State and Society in Contemporary South Korea, edited by Hagen Koo, 95-130. Ithaca: Cornell University Press.

Em, Henry H. 2013. The Great Enterprise: Sovereignty and Historiography in Modern Korea. Durham: Duke University Press.

Evans, Peter B. 1995. Embedded Autonomy: States and Industrial Transformation. Princeton: Princeton University Press.

Gellner, Ernest. 1968. "Holism Versus Individualism." In Readings in the Philosophy of the Social Sciences edited by May Brodbeck, 254-268. New York: Macmillan.

.2008. Nations and Nationalism. 2nd ed. Ithaca: Cornell University Press.

Gourevitch, Peter A. 1989. "Keynesian Politics: The Political Sources of Economic Policy Choices." In The Political Power of Economic Ideas: Keynesianism across Nations, edited by Peter A. Hall, 87-106. Princeton: Princeton University Press.

Greenfeld, Liah. 2001. The Spirit of Capitalism: Nationalism and Economic Growth. Cambridge: Harvard University Press.

Haas, Ernst B. 1986. "What is Nationalism and Why should we Study it?" International Organization 40 (3): 707-744.

Haggard, Stephan. 1990. Pathways from the Periphery: The Politics of Growth in the Newly Industrializing Countries. Ithaca: Cornell University Press.

Hall, Derek. 2005. "Japanese Spirit, Western Economic: The Continuing Salience of Economic Nationalism in Japan." In Economic Nationalism in a 
Globalizing World, edited by Eric Helleiner and Andreas Pickel, 118-140. Ithaca: Cornell University Press.

Helleiner, E. 2002. "Economic Nationalism as a Challenge to Economic Liberalism? Lessons from the 19th Century." International Studies Quarterly 46 (3): 307-329.

Helleiner, Eric and Andreas Pickel, eds. 2005. Economic Nationalism in a Globalizing World. Cornell Studies in Political Economy. Ithaca: Cornell University Press.

Hirschman, Albert O. 2013. The Passions and the Interests: Political Arguments for Capitalism before its Triumph. Princeton Classics ed. Princeton: Princeton University Press.

Hughes, Theodore H. 2012. Literature and Film in Cold War South Korea: Freedom's Frontier. New York: Columbia University Press.

Hwang, Kyung Moon. 2016. Rationalizing Korea: The Rise of the Modern State, 1894-1945. Oakland: University of California Press.

Jager, Sheila Miyoshi. 2003. Narratives of Nation Building in Korea: A Genealogy of Patriotism. Armonk, NY: M.E. Sharpe.

Jayasuriya, Kanishka. 2005. "Beyond Institutional Fetishism: From the Developmental to the Regulatory State." New Political Economy 10 (3): 381-387.

Kang, Jin Woong. 2012. "The Disciplinary Politics of Antagonistic Nationalism in Militarized South and North Korea." Nations and Nationalism 18 (4): 684-700.

Kang, Myungkoo. 2011. "Compressed Modernization and the Formation of a Developmentalist Mentalité." In Reassessing the Park Chung Hee Era, 1961-1979: Development, Political Thought, Democracy, \& Cultural Influence, edited by Hyung A Kim and Clark W. Sorensen, 166-186. Seattle: University of Washington Press.

Kihl, Young Wahn. 2005. Transforming Korean Politics: Democracy, Reform, and Culture. Armonk, NY: M.E. Sharpe, Inc.

Kim, Andrew Eungi and Gil Sung Park. 2003. "Nationalism, Confucianism, Work Ethic and

Industrialization in South Korea." Journal of Contemporary Asia 33 (1): 37-49.

Kim, Dong No. 2013. "National Identity and Class Interest in the Peasant Movements of the Colonial Period." In Colonial Rule and Social Change in Korea, 1910-1945, edited by Hong Yung Lee, Yong-ch'ul Ha and Clark W. Sorensen, 140-172. Seattle: University of Washington Press.

Kim, Eun Mee and Gil Sung Park. 2011. "The Chaebol." In The Park Chung Hee

Era: The Transformation of South Korea, edited by Byung-Kook Kim and

Ezra F. Vogel, 265-294. Cambridge: Harvard University Press.

Kim, Hyung A. 2004. Korea's Development Under Park Chung Hee: Rapid 
Industrialization, 1961-79. New York: Routledge.

Kim, June Dong. 1997. "Impact of Foreign Direct Investment Liberalization: The

Case of Korea." Korea Institute of International Economic Policy (KIEP

Working Paper 97-01)

Kim, Jun Il and Jongryn Mo. 1999. "Democratization and Macroeconomic Policy." In Democracy and the Korean Economy, edited by Jongryn Mo and Chung-in Moon, 73-96. Stanford, CA: Hoover Institute Press.

Kim, Kyong Ju. 2006. The Development of Modern South Korea: State Formation, Capitalist Development and National Identity. London: Routledge.

Kim, Samuel S. 2000. "Korea's Segyehwa Drive: Promise Versus Performance."

In Korea's Globalization, edited by Samuel S. Kim, 242-281. Cambridge: Cambridge University Press.

Kim, Young Jak. 2011. "Park Chung Hee's Governing Ideal: Impact on National

Consciousness and Identity." In Reassessing the Park Chung Hee Era, 1961-1979: Development, Political Thought, Democracy, \& Cultural Influence, edited by Hyung A Kim and Clark W. Sorensen, 95-106. Seattle: University of Washington Press.

Kimiya, Tadashi. 2011. "The Cold War and the Political Economy of the Park Chung Hee Regime." In Reassessing the Park Chung Hee Era, 1961-1979: Development, Political Thought, Democracy, \& Cultural Influence, edited by Hyung A Kim and Clark W. Sorensen, 66-82. Seattle: University of Washington Press.

Koo, Hagen. 2001. Korean Workers: The Culture and Politics of Class Formation. Ithaca: Cornell University Press.

. 1999. "Modernity in South Korea: An Alternative Narrative." Thesis Eleven 57 (1): 53-64.

Lechevalier, Sébastien, Pauline Debanes, and Shin Wonkyu. 2017. Financialization and Industrial Policies in Japan and Korea: Evolving Complementarities and Loss of Institutional Capabilities: INCAS Discussion Paper Series $2016 \# 01$.

Lee, Chae Jin. 2000. "South Korean Foreign Relations Face the Globalization Challenges." In Korea's Globalization, edited by Samuel S. Kim, 170-195. Cambridge: Cambridge University Press.

Lee, Jin Kyung. 2010. Service Economies: Militarism, Sex Work, Migrant Labor in South Korea. Minneapolis: University of Minnesota Press.

Lee, Yeon ho. 1997. "The Limits of Economic Globalization in East Asian Developmental States." The Pacific Review 10 (3): 366-390.

Levi-Faur, David. 1997. "Friedrich List and the Political Economy of the Nation-State." Review of International Political Economy 4 (1): 154-178.

Mansfield, Edward D. and Diana C. Mutz. 2009. "Support for Free Trade: 
Self-Interest, Sociotropic Politics, and Out-Group Anxiety." International Organization 63 (03): 425-457.

Moon, Chung In. 1999. "Democratization and Globalization as Ideological and Political Foundations of Economic Policies." In Democracy and the Korean Economy, edited by Chung-In Moon and Jongryn Mo, 1-34. Stanford: Hoover Institution Press.

Moon, Chung In and Byung Joon Jun. 2011. "Modernization Strategy: Ideas and Influences." In The Park Chung Hee Era: The Transformation of South Korea, edited by Byung-kook Kim and Ezra F. Vogel, 115-139. Cambridge: Harvard University Press.

Moon, Seungsook. 2009. "The Cultural Politics of Remembering Park Chung Hee." The Asia-Pacific Journal 7 (19): 1-33.

. 2005. Militarized Modernity and Gendered Citizenship in South Korea. Politics, History, and Culture. Durham N.C.: Duke University Press.

Nakano, Takeshi. 2004. "Theorising Economic Nationalism." Nations and Nationalism 10 (3): 211-229.

Nelson, Laura C. 2000. Measured Excess: Status, Gender, and Consumer Nationalism in South Korea. New York: Columbia University Press.

Pai, Hyung Il. 2000. Constructing "Korean" Origins: A Critical Review of Archaeology, Historiography, and Racial Myth in Korean State-Formation Theories. Harvard East Asian Monographs. Vol. 187. Cambridge: Harvard University Asia Center.

Pak, Sejin. 1998. "Two Forces of Democratisation in Korea." Journal of Contemporary Asia 28 (1): 45-73.

Pang, Eul Soo. 2000. "The Financial Crisis of 1997-98 and the End of the Asian

Developmental State." Contemporary Southeast Asia 22 (3): 570-593.

Park, Myung Lim. 2011. "The Chaeya." In The Park Chung Hee Era: The Transformation of South Korea, edited by Byung-Kook Kim and Ezra F. Vogel, 373-400. Cambridge: Harvard University Press.

Park, Chung Hee. 1970a. Our Nation's Path: Ideology of Social Reconstruction. 2nd ed. Seoul: Hollym Corp.

. 1970b. The Country, the Revolution, and I. 2nd ed. Seoul: Hollym Corp.

Park, So Jin. 2011. "Educational Manager Mothers as Neoliberal Maternal Subjects." In New Millennium South Korea: Neoliberal Capitalism and Transnational Movements, edited by Jesook Song, 101-114. London: Routledge.

Peck, Jamie. 2010. Constructions of Neoliberal Reason. Oxford: Oxford University Press.

Pickel, Andreas. 2005. "Introduction. False Options: Reconceptualizing Economic Nationalism in a Globalizing World." In Economic Nationalism in a Globalizing World, edited by Eric Helleiner and Andreas Pickel, 1-20. 
Ithaca: Cornell University Press.

Pirie, Iain. 2006. "Economic Crisis and the Construction of a Neo-Liberal Regulatory Regime in Korea." Competition \& Change 10 (1): 49-71. .2008. The Korean Developmental State: From Dirigisme to Neo-Liberalism. New York: Routledge.

Ryu, Youngju. 2016. Writers of the Winter Republic: Literature and Resistance in Park Chung Hee's Korea. Honolulu: University of Hawaii Press.

Saxer, Carl J. 2013. "Democratization, Globalization and the Linkage of Domestic and Foreign Policy in South Korea." The Pacific Review 26 (2): 177-198.

Schmid, Andre. 2002. Korea between Empires, 1895-1919. Studies of the East Asian Institute. New York: Columbia University Press.

Shin, Gi Wook. 2006. Ethnic Nationalism in Korea: Genealogy, Politics, and Legacy. Studies of the Walter H. Shorenstein Asia-Pacific Research Center. Stanford: Stanford University Press.

. 1998. "Nation, History, and Politics." In Nationalism and the Construction of Korean Identity, edited by Hyung Il Pai and Timothy R. Tangherlini, 148-165. Berkeley: Institute for East Asian Studies, University of California.

Shin, Gi Wook and Paul Y. Chang, eds. 2011. South Korean Social Movements: From Democracy to Civil Society. New York: Routledge.

Shulman, Stephen. 2000. "Nationalist Sources of International Economic Integration." International Studies Quarterly 44 (3): 365-390.

Smith, Anthony D. 2010. Nationalism. 2nd ed. Cambridge, UK: Polity Press.

Sohn, Jie Ae. 1993. "Globalizing the Economy: With Open Arms." Business Korea, December 1993.

Stubbs, Richard. 2009. "What Ever Happened to the East Asian Developmental State? The Unfolding Debate." The Pacific Review 22 (1): 1-22.

Thurbon, Elizabeth. 2016. Developmental Mindset: Revival of Financial Activism in South Korea. Ithaca: Cornell University Press.

2003. "Ideational Inconsistency and Institutional Incapacity: Why Financial Liberalisation in South Korea Went Horribly Wrong." New Political Economy 8 (3): 341-361.

Thurbon, Elizabeth and Linda Weiss. 2006. "Investing in Openness: The Evolution of FDI Strategy in South Korea and Taiwan." New Political Economy 11 (1): 1-22.

Trentmann, Frank. 1998. "Political Culture and Political Economy: Interest, Ideology and Free Trade." Review of International Political Economy 5 (2): 217-251.

Vogel, Steven K. 1999. "When Interests are Not Preferences: The Cautionary Tale of Japanese Consumers." Comparative Politics 31 (2): 187-207. 
Weiss, Linda. 2003. "Guiding Globalisation in East Asia: New Roles for Old Developmental States." In States in the Global Economy: Bringing Domestic Institutions Back in, edited by Linda Weiss, 245-270. Cambridge: Cambridge University Press.

Wells, Kenneth M., ed. 1995. South Korea's Minjung Movement: The Culture and Politics of Dissidence. Honolulu: University of Hawaii Press.

Woo, Jung En. 1991. Race to the Swift: State and Finance in Korean Industrialization. New York: Columbia University Press. . 2005. "Back to Basics: Ideology, Nationalism, and Asian Values in East Asia." In Economic Nationalism in a Globalizing World, edited by Eric Helleiner and Andreas Pickel, 91-118. Ithaca: Cornell University Press.

\section{ENDNOTES}

1 In tracing the etymology of interest Hirschman $(2013,32)$ highlights that its original 'pre-economistic' formulation was "by no means limited to the material aspects of a person's welfare; rather, it comprised the totality of human aspirations."

2 Certainly, discourses surrounding nationalism and modernization have a history in Korea that stretches back to the late-Joseon period. Schmid (2002), Hwang (2016), and Em (2013) offer insightful accounts of how these twin forces emerged and gestated during this time.

3 Carter Eckert's (2016) recent book on the roots of Park Chun Hee's ideology provides an excellent overview of the emergence of his militarized conception of modernization during the colonial era.

4 Ryu $(2016,32)$ also highlights that this movement towards greater economic coordination with Japan also coincided with official action to ban all Japanese cultural and media products from the Korean marketplace in an effort to demonstrate its "sensitivity to the "national sentiment"."

5 The phrase 'global mind' in the title of this section is inspired by many interactions with students in Korea who informed me that cultivating a 'global mind' was one of their primary educational goals. I have profited immensely from our discussions regarding what exactly was meant by this term.

6 Shin $(2006,215)$ also draw a direct comparison between Park's developmental programs and Kim young Sam's globalization drive in a as much as the both placed an "emphasis on Korea's native culture and national identity as integral to their respective national development projects." 